\title{
Creeping Bentgrass Quality following Preemergence and Postemergence Herbicide Applications
}

\author{
B. Jack Johnson ${ }^{1}$ \\ Department of Crop and Soil Sciences, University of Georgia, Georgia \\ Station, Griffin, GA 30223-1797
}

Additional index words. Agrostis stolonifera, turf quality, turf cover, dithiopyr, diclofop, quinclorac, MSMA

\begin{abstract}
Three field experiments were conducted to determine if several preemergence and postemergence herbicides were safe to apply to creeping bentgrass (Agrostis stolonifera L. 'Penncross') maintained at putting green height. When dithiopyr was applied at preemergence in late February or early March, the emulsifiable concentrate formulation $\left(\leq 1.7 \mathrm{~kg} \cdot \mathrm{ha}^{-1}\right)$ and granular formulation $\left(\leq 1.1 \mathrm{~kg} \cdot \mathrm{ha}^{-1}\right)$ did not reduce the quality or cover of creeping bentgrass. Applied at preemergence, bensulide plus oxadiazon at $6.7+1.7$ $\mathrm{kg} \cdot \mathrm{ha}^{-1}$ and $13.4+3.4 \mathrm{~kg} \cdot \mathrm{ha}^{-1}$ reduced turfgrass quality for 2 to 3 weeks and 8 weeks after treatment, respectively. When MON 12051 and monosodium salt of methylarsonic acid (MSMA) $\left(\leq 0.14\right.$ and $\leq 2.2 \mathrm{~kg} \cdot \mathrm{ha}^{-1}$, respectively) were applied at postemergence to creeping bentgrass in early June, the reduction in turfgrass quality varied from slight to moderate for 1 to 2 weeks, but turfgrass fully recovered with no effect on turfgrass cover. Quinclorac applied at postemergence in early June at $\geq 0.6 \mathrm{~kg} \cdot \mathrm{ha}^{-1}$ severely reduced creeping bentgrass quality and cover for $\geq 8$ weeks. Diclofop at $0.6 \mathrm{~kg} \cdot \mathrm{ha}^{-1}$ applied to creeping bentgrass in June, July, or August maintained consistently higher quality and cover ratings than when applied at $\geq 1.1 \mathrm{~kg} \cdot \mathrm{ha}^{-1}$. Diclofop applied at $0.6 \mathrm{~kg} \cdot \mathrm{ha}^{-1}$ in June and repeated at the same rate in July reduced quality of creeping bentgrass less than when applied at $1.1 \mathrm{~kg}^{-h^{-1}}$ at any date. Chemical names used: $O, O$-bis (1-methylethyl) $S-\{2-[($ phenylsulfonyl)amino $]$ ethyl $\}$ phosphorodithioate (bensulide); ( \pm )-2-[4-(2,4-dichlorophenoxy)phenoxy]propanoic acid (diclofop); $S, S$-dimethyl-2-(difluoromethyl)-4-(2-methylpropyl)-6-(trifluoromethyl)-3,5pyridinedicarbothioate (dithiopyr); methyl-5-\{[(4,6-dimethoxy-2-pyrimidinyl)amino] carbonylaminosulfonyl\}-3-chloro-1-methyl-1-H-pyrazol-4-carboxylate (MON 12051); 3[2,4-dicloro-5-(1-methylethoxy)phenyl]-5-(1,1-dimethylethyl)-1,3,4-oxadiazol-2-(3H)-one (oxadiazon); 3,7-dicloro-8-quinolinecarboxylic acid (quinclorac).
\end{abstract}

Creeping bentgrass is used widely on putting greens throughout the southeastern United States' transitional zone. Because the grass grows under heat stress for most of late spring and summer, crabgrasses (Digitaria spp.) and goosegrass [Eleusine indica (L.) Gaertn.] are often severe weed problems. Creeping bentgrass is sensitive to herbicides when grown under stress from high temperatures and humidity and intensive disease pressure. Therefore, the selection of herbicides useful for weed control in creeping bentgrass greens is limited.

Preemergence treatments of bensulide plus oxadiazon controlled crabgrass and goosegrass (Johnson, 1982; Johnson and Murphy, 1989) without severely injuring creeping bentgrass

Received for publication 15 Nov. 1993. Accepted for publication 23 Mar. 1994. Supported by state and Hatch Act funds allocated to the Georgia Agricultural Experiment Stations. I thank J. Davis, station statistician, for his cooperation in these studies, and gratefully acknowledge W. Olson, M. Gilmer, and T. Dinkins for technical assistance. The cost of publishing this paper was defrayed in part by the payment of page charges. Under postal regulations, this paper therefore must be hereby marked advertisement solely to indicate this fact.

'Professor.
(Johnson, 1987, 1990). When injury did occur, it was a slight foliar discoloration, and the turfgrass fully recovered with no stand loss. Dithiopyr is another preemergence herbicide that controls crabgrass and goosegrass (Dernoeden and Krouse, 1991; Johnson and Murphy, 1989, 1993). Creeping bentgrass tolerated dithiopyr emulsifiable concentrate formulation (EC) when applied at $\leq 0.8 \mathrm{~kg} \cdot \mathrm{ha}^{-1}$ (Dernoeden et al., 1993). The control of crabgrass and goosegrass was consistently higher when treated with dithiopyr granular formulation $(\mathrm{G})$ than with EC formulation (Johnson and Murphy, 1989, 1993). Studies conducted in Maryland (Dernoeden et al., 1993) demonstrated that the tolerance of creeping bentgrass to dithiopyr $\mathrm{G}$ at $0.6 \mathrm{~kg} \cdot \mathrm{ha}^{-1}$ was equal to or better than $6.7 \mathrm{~kg}$ bensulide/ha plus $1.7 \mathrm{~kg}$ oxadiazon/ha when ratings were made within 4 weeks after treatment.

Postemergence herbicides often have to be applied to control nontreated weeds or when preemergence herbicides failed to provide fullseason control. MSMA (Johnson, 1975) and quinclorac (Bhowmik and O'Toole, 1991; Chism and Bingham, 1991; Johnson, 1994) control crabgrass at postemergence, and diclofop controls goosegrass at postemergence (Johnson and Murphy, 1994; McCarty, 1991). Research reported in Massachusetts (Bhowmik and O'Toole, 1991) indicated that creeping bentgrass tolerated quinclorac at $\leq 0.8 \mathrm{~kg} \cdot \mathrm{ha}^{-1}$, but turfgrass was injured $21 \%$ within 2 weeks after treatment with diclofop at $1.1 \mathrm{~kg} \cdot \mathrm{ha}^{-1}$ in Maryland (Dernoeden, 1987).

Throughout the southeastern United States, creeping bentgrass is affected by summer stresses. Because herbicides are needed to control weeds during this period, additional herbicide information is needed on this turfgrass species. Therefore, I initiated experiments with herbicides on a creeping bentgrass green to determine a) the tolerance of creeping bentgrass to several preemergence and postemergence herbicides and b) the time interval needed for turfgrass recovery.

\section{Materials and Methods}

Three herbicide experiments were conducted on an established 'Penncross' creeping bentgrass research green in Griffin, Ga.

Preemergence herbicides. Preemergence herbicides were applied as single applications on 3 Mar. 1992 and 24 Feb. 1993 at the following rates $\left(\mathrm{kg} \cdot \mathrm{ha}^{-1}\right)$ : bensulide plus oxadiazon, $6.7+1.7$ and $13.4+3.4$; dithiopyr G, $0.3,0.6,0.8$, and 1.1 ; and dithiopyr EC, 0.8 and 1.7. A nontreated control also was included. Treatments were applied to the same plots each year.

Postemergence herbicides. Postemergence herbicides were applied as single applications on 2 June 1992 and 1993 at the following rates $\left(\mathrm{kg} \cdot \mathrm{ha}^{-1}\right)$ : MON 12051, 0.07 and 0.14; quinclorac, 0.6, 1.1, and 1.7; and MSMA, 1.1 and 2.2. A nontreated control was included. Treatments were applied to the same plots each year. MON 12051 is a postemergence herbicide for purple (Cyperus rotundus L.) and yellow nutsedge (C. esculentus L.) control. Quinclorac is an experimental herbicide in the olinecarboxylic acid family, and is being evaluated to control crabgrass in turfgrasses.

Diclofop is an aryl-ory-phenoxypropionate postemergence herbicide used for goosegrass control in bermudagrass (Cynodon spp.). Diclofop was applied as single and repeated application(s) from 1991 to 1993 . A nontreated control also was included. Single applications were made at $0.6,1.1$, and $1.7 \mathrm{~kg} \cdot \mathrm{ha}^{-1}$ to separate plots on 15 June, 17 July, and 15 Aug. ( \pm 2 days). Repeated applications were made at $0.6 \mathrm{~kg} \cdot \mathrm{ha}^{-1}$ per application on 15 June plus 17 July and 17 July plus 15 Aug. Treatments were applied to different plots each year. Data from 1992 were discarded because clogged drains resulted in above normal phytotoxicity to the turf.

General information. Dithiopyr G was mixed with sand and applied by hand. All other herbicides were applied as a broadcast spray in 355 liters of water/ha.

The creeping bentgrass root zone was a U.S. Golf Association soil mixture consisting of $\left({\left.\mathrm{g} \cdot \mathrm{kg}^{-1}\right)}^{-1} 970\right.$ sand, 20 silt, and 10 clay. Creeping bentgrass was fertilized with $294 \mathrm{~N}-$ $12 \mathrm{P}-124 \mathrm{~K}$ each year. The schedule for $\mathrm{N}$ was (in kg.ha ${ }^{-1}$ ) 12 in March, June, July, and August; 25 in February and December; and 50 in April, September, October, and November. 
Two-thirds of $\mathrm{N}$ was water soluble, and onethird was water insoluble. Phosphorus was applied at $6 \mathrm{~kg} \cdot \mathrm{ha}^{-1}$ in April and September and $\mathrm{K}$ at $41 \mathrm{~kg} \cdot \mathrm{ha}^{-1}$ in February, August, and November. Actively growing creeping bentgrass was mowed three times per week (4 $\mathrm{mm}$ high) and clippings were removed. Irrigation was applied as needed to maintain optimum growth. Fungicides and insecticides were used to prevent disease and insect problems.

Turf quality and coverage ratings were visually estimated at various times after the preemergence and postemergence herbicide treatments. Turf quality ratings were based on a scale from 1 to $10(1=$ turf brown and $10=$ dark-green, uniformly dense turf) and adjusted to a percentage of the nontreated control. Turf cover ratings were based on a scale from 1 to $10(1=$ no turf and $10=$ uniform complete cover) and adjusted to a percentage of the nontreated control. On this scale, $<90$ would not be acceptable.

The design was a randomized complete block with three replications. Individual plots were $1.5 \times 3 \mathrm{~m}$. Using SAS's general linear model procedure, an analyses of variance was performed within and across years (SAS Institute, 1982). There was no year $\times$ treatment interaction in the preemergence herbicide experiment, but a year $\times$ treatment interaction occurred in the postemergence experiments. The treatment means were separated by least significant difference at $P \leq 0.05$.

Table 1. Influence of preemergence herbicides on quality of creeping bentgrass maintained as a putting green at various evaluation dates, Griffin, Ga.

\begin{tabular}{|c|c|c|c|c|c|c|c|}
\hline \multirow[b]{3}{*}{ Herbicide $^{y}$} & \multirow{3}{*}{$\begin{array}{c}\text { Rate } \\
\left(\mathrm{kg} \cdot \mathrm{ha}^{-1}\right)\end{array}$} & \multicolumn{6}{|c|}{$\%$ Nontreated control } \\
\hline & & \multicolumn{6}{|c|}{ Turfgrass quality } \\
\hline & & 17 Mar. & 30 Mar. & 14 Apr. & 28 Apr. & 12 May & 16 June \\
\hline Nontreated & -- & 100 & 100 & 100 & 100 & 100 & 100 \\
\hline \multirow[t]{4}{*}{ Dithiopyr (G) } & 0.3 & 97 & 99 & 101 & 101 & 101 & 101 \\
\hline & 0.6 & 94 & 99 & 100 & 100 & 101 & 100 \\
\hline & 0.8 & 97 & 99 & 99 & 101 & 100 & 100 \\
\hline & 1.1 & 96 & 99 & 101 & 100 & 101 & 102 \\
\hline \multirow[t]{2}{*}{ Dithiopyr (EC) } & 0.8 & 97 & 99 & 100 & 97 & 100 & 100 \\
\hline & 1.7 & 96 & 96 & 100 & 99 & 100 & 100 \\
\hline \multirow[t]{2}{*}{ Bensulide + oxadiazon } & $6.7+1.7$ & 84 & 94 & 98 & 101 & 101 & 101 \\
\hline & $13.4+3.4$ & 80 & 88 & 91 & 92 & 96 & 100 \\
\hline $\mathrm{LSD}_{0.05}$ & & 9 & 6 & 6 & 5 & NS & NS \\
\hline
\end{tabular}

${ }^{2}$ Turfgrass quality ratings are 2-year averages.

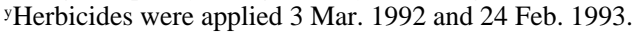

\section{Results and Discussion}

Preemergence herbicides. Dithiopyr applied as G or EC did not reduce quality of creeping bentgrass compared to turfgrass in nontreated plots at anytime during the spring or early summer (Table 1). The quality data from plots treated with the EC agree with those reported in an earlier study, with one exception (Shim and Johnson, 1992). In that study, the foliar injury was $(\leq 20 \%)$ temporary in 1 of 2 years when treated at $1.1 \mathrm{~kg} \cdot \mathrm{ha}^{-1}$, but the turfgrass fully recovered within 4 weeks. When either dithiopyr EC or $\mathrm{G}$ was applied at 0.6 $\mathrm{kg} \cdot \mathrm{ha}^{-1}$ to creeping bentgrass in Iowa (Dernoeden et al., 1993), root growth was reduced 8 weeks after treatment in 1 of 2 years. When the same treatment was applied to creeping bentgrass in Maryland (Dernoeden et al., 1993), there were some instances where root growth was less than for nontreated turfgrass at 4 weeks but not at 8 weeks.

In earlier studies (Johnson and Murphy, 1989, 1993), there was an advantage in using dithiopyr $\mathrm{G}$ for crabgrass and goosegrass control, compared to EC. The less active ingredient of dithiopyr $\mathrm{G}\left(0.4 \mathrm{~kg} \cdot \mathrm{ha}^{-1}\right)$ was required to maintain $86 \%$ crabgrass control compared to that of the EC $\left(0.8 \mathrm{~kg} \cdot \mathrm{ha}^{-1}\right) . \mathrm{G}$ at $0.6 \mathrm{~kg} \cdot \mathrm{ha}^{-1}$ also provided consistently higher goosegrass Therefore, the favorable tolerance of creeping bentgrass to dithiopyr $\mathrm{G}$ (Table 1) makes it a control $(84 \%)$ than didEC at $0.8 \mathrm{~kg} \cdot \mathrm{ha}^{-1}(65 \%)$. good choice for consistent crabgrass and goosegrass control throughout the spring and summer.

Bensulide plus oxadiazon reduced the quality of creeping bentgrass within 2 to 3 weeks after treatment (Table 1). The reduction was related to foliar discoloration with little or no turfgrass thinning. Turfgrass treated at $6.7+$ $1.7 \mathrm{~kg} \cdot \mathrm{ha}^{-1}$ had recovered by 30 Mar., but turfgrass treated at $13.4+3.4 \mathrm{~kg} \cdot \mathrm{ha}^{-1}$ did not recover until mid-May. The response from 6.7 $+1.7 \mathrm{~kg} \cdot \mathrm{ha}^{-1}$ was similar to Johnson's (1987). These results confirm that when bensulide plus oxadiazon are applied to creeping bentgrass, slight discoloration may occur within a few days after treatment, but turfgrass fully recovers without any stand loss. Turfgrass injury increased when bensulide plus oxadiazon rates were increased. Therefore, the maximum application rate of bensulide plus oxadiazon seems to be $6.7+1.7 \mathrm{~kg} \cdot \mathrm{ha}^{-1}$. There was no effect of any preemergence herbicide treatment on turf cover compared to nontreated turf in April or later (data not given).

Postemergence herbicides. During 1992 and 1993, when quinclorac was applied at $\geq 0.6 \mathrm{~kg} \cdot \mathrm{ha}^{-1}$, severe injury occurred to creeping bentgrass. Creeping bentgrass quality (Table 2) and cover (Table 3) were lower for 8 weeks following treatments in quincloractreated plots, compared to nontreated turf. In 1993, the quality of creeping bentgrass treated with $\leq 1.1 \mathrm{~kg} \cdot \mathrm{ha}^{-1}$ recovered by 10 weeks, but turfgrass treated at $1.7 \mathrm{~kg} \cdot \mathrm{ha}^{-1}$ did not recover. Creeping bentgrass maintained at a 4-mm height and treated with quinclorac at 0.6 $\mathrm{kg} \cdot \mathrm{ha}^{-1}$ reduced turfgrass quality $42 \%$ by 4 weeks after treatment in 1992 and $51 \%$ by 2 weeks after treatment in 1993. These results agree with those reported on creeping bentgrass maintained at a 5-mm height in New Jersey (Sciarappa, 1991). In that study, quinclorac applied at $0.8 \mathrm{~kg} \cdot \mathrm{ha}^{-1}$ reduced the quality of the turfgrass by $27 \%$ within 1 week after treatment. However, my results differ from Bhowmik and O'Toole's (1991) Massachusetts results, in which quinclorac injury was slight and rarely noticeable for 3 weeks after treatment at $\leq 0.8 \mathrm{~kg} \cdot \mathrm{ha}^{-1}$ in early September. The higher injury in Georgia likely was related to plant stress when quinclorac treatments were made in June, compared to less stress

Table 2. Influence of postemergence herbicides at various weeks after treatment on quality of creeping bentgrass maintained as a putting green, Griffin, Ga.

\begin{tabular}{|c|c|c|c|c|c|c|c|c|c|c|}
\hline \multirow[b]{5}{*}{ Herbicide $^{y}$} & \multirow{5}{*}{$\begin{array}{c}\text { Rate } \\
\left(\mathrm{kg} \cdot \mathrm{ha}^{-1}\right)\end{array}$} & \multicolumn{9}{|c|}{$\%$ Nontreated control } \\
\hline & & \multicolumn{9}{|c|}{ Turfgrass quality ${ }^{z}$} \\
\hline & & \multicolumn{4}{|c|}{1992} & \multicolumn{5}{|c|}{1993} \\
\hline & & \multicolumn{4}{|c|}{ Weeks after treatment } & \multicolumn{5}{|c|}{ Weeks after treatment } \\
\hline & & 1 & 2 & 4 & 8 & 1 & 2 & 4 & 8 & 10 \\
\hline Nontreated & --- & 100 & 100 & 100 & 100 & 100 & 100 & 100 & 100 & 100 \\
\hline \multirow[t]{3}{*}{ Quinclorac } & 0.6 & 59 & 68 & 58 & 72 & 78 & 49 & 67 & 86 & 103 \\
\hline & 1.1 & 47 & 57 & 58 & 76 & 61 & 47 & 63 & 87 & 96 \\
\hline & 1.7 & 47 & 44 & 42 & 54 & 55 & 42 & 50 & 71 & 88 \\
\hline \multirow[t]{2}{*}{ MON 12051} & 0.07 & 77 & 90 & 95 & 104 & 107 & 93 & 120 & 90 & 97 \\
\hline & 0.14 & 82 & 96 & 91 & 100 & 81 & 91 & 105 & 96 & 97 \\
\hline \multirow[t]{2}{*}{ MSMA } & 1.1 & 80 & 93 & 80 & 103 & 96 & 96 & 122 & 90 & 101 \\
\hline & 2.2 & 69 & 101 & 97 & 103 & 81 & 97 & 118 & 99 & 103 \\
\hline $\mathrm{LSD}_{0.05}$ & & 16 & 17 & 24 & 22 & 20 & 5 & 22 & 10 & 11 \\
\hline
\end{tabular}

${ }^{2}$ Turfgrass quality ratings were made at the times indicated and are based on the percentage of nontreated check.

${ }^{y}$ Herbicides were applied 2 June 1992 and 1993. 
when treatments were made in September in Massachusetts. These results indicate that quinclorac should not be applied to puttinggreen height creeping bentgrass in the southeastern United States during stress periods.

When MON 12051 was applied once to creeping bentgrass at $\leq 0.14 \mathrm{~kg} \cdot \mathrm{ha}^{-1}$, the quality was reduced slightly to moderately within 1 to 2 weeks after treatment (Table 2), but it did not affect turf cover by 5 weeks after treatment (Table 3). In all instances, creeping bentgrass treated with MON 12051 recovered fully by 2 weeks in 1992 and by 4 weeks in 1993 . For comparison, the quality of turfgrass treated once with MON 12051 was similar to that treated once with MSMA at $\leq 2.2 \mathrm{~kg} \cdot \mathrm{ha}^{-1}$. Creeping bentgrass treated once with MSMA at 2.2 $\mathrm{kg} \cdot \mathrm{ha}^{-1}$ reduced turfgrass quality $31 \%$ and $19 \%$ at 1 week after treatment in 1992 and 1993, respectively. By 2 weeks, turfgrass recovered completely.

Postemergence diclofop experiment. Diclofop applied at $1.1 \mathrm{~kg} \cdot \mathrm{ha}^{-1}$ generally controlled goosegrass as effectively as higher rates (Johnson and Murphy, 1994; McCarty, 1991). When diclofop was applied once at $1.1 \mathrm{~kg} \cdot \mathrm{ha}^{-1}$ to creeping bentgrass in June, turfgrass quality was reduced only 5\% in 1991 but $24 \%$ in 1993

Table 3. Influence of postemergence herbicides at various weeks after treatment on cover of creeping bentgrass maintained as a putting green, Griffin, Ga.

\begin{tabular}{|c|c|c|c|}
\hline \multirow[b]{3}{*}{ Herbicide $^{y}$} & \multirow{3}{*}{$\begin{array}{c}\text { Rate } \\
\left(\mathrm{kg} \cdot \mathrm{ha}^{-1}\right)\end{array}$} & \multicolumn{2}{|c|}{$\frac{\% \text { Nontreated control }}{\text { Turfgrass cover }^{2}}$} \\
\hline & & \multicolumn{2}{|c|}{ Weeks after treatmen } \\
\hline & & 5 & 8 \\
\hline Nontreated & --- & 100 & 100 \\
\hline \multirow{2}{*}{ MON 12051} & 0.07 & 98 & 98 \\
\hline & 0.14 & 92 & 97 \\
\hline \multirow[t]{3}{*}{ Quinclorac } & 0.6 & 67 & 79 \\
\hline & 1.1 & 65 & 76 \\
\hline & 1.7 & 57 & 56 \\
\hline \multirow[t]{2}{*}{ MSMA } & 1.1 & 100 & 96 \\
\hline & 2.2 & 100 & 99 \\
\hline $\mathrm{LSD}_{0.05}$ & & 11 & 9 \\
\hline
\end{tabular}

${ }^{2}$ Turfgrass cover ratings were made at the times indicated and are averages from 2 years and based on the percentage of nontreated control.

${ }^{y}$ Herbicides were applied 2 June 1992 and 1993.
(Table 4). Turfgrass treated on 15 June 1993 did not recover until 26 July. The quality of creeping bentgrass was not reduced as much in 1993 when treated 15 June at $0.6 \mathrm{~kg} \cdot \mathrm{ha}^{-1}$, compared to $\geq 1.1 \mathrm{~kg} \cdot \mathrm{ha}^{-1}$. The difference in results for 1991 and 1992 is unexplained. The daily mean low-high temperatures for 2 weeks following treatment was similar in both years (24C).

When diclofop treatments were delayed until 17 July or 15 Aug., the treated creeping bentgrass quality was reduced more during 1991 than when treatments were made during the same period in 1993 (Table 4). The difference in quality ratings was not explained by temperature. The daily mean low-high temperatures for 2 weeks following diclofop treatments were lower in 1991 (July $=26 \mathrm{C}$; August $=24 \mathrm{C}$ ) than during 1993 (July $=29 \mathrm{C}$; August $=27 \mathrm{C}$ ). Turfgrass treated at $1.1 \mathrm{~kg} \cdot \mathrm{ha}^{-1}$ on 17 July required 5 weeks to recover (22 Aug.), but turfgrass treated at the same rate on 15 Aug. required only 2 weeks (28 Aug.) to recover. The faster recovery from the August treatment was not related to temperature. The daily mean low-high temperature for 2 weeks following treatment in July was $26 \mathrm{C}$, compared to $24 \mathrm{C}$ for the same period following the August treatment.

Even though weather conditions and other management practices were similar both years, there was no single preferred diclofop application date when applied at $1.1 \mathrm{~kg} \cdot \mathrm{ha}^{-1}$ (Table 4 ). At this rate, the maximum reduction in turfgrass quality was $24 \%$ when applied on 15 June $1993,26 \%$ when applied on 17 July 1992, and $22 \%$ when applied on 15 Aug. 1992. In most cases when diclofop reduced the quality of creeping bentgrass, the turfgrass cover also was reduced (data not given). The turfgrass cover fully recovered within 2 weeks after the June treatment and 3 to 4 weeks after the July and August treatments. These results agree with Dernoeden's (1987) Maryland results, in which creeping bentgrass was injured immediately after treatment with diclofop at 1.1 $\mathrm{kg} \cdot \mathrm{ha}^{-1}$ but recovered within 3 to 4 weeks.

Two diclofop applications at $0.6 \mathrm{~kg} \cdot \mathrm{ha}^{-1}$ on 15 June plus 17 July improved the creeping bentgrass quality slightly, compared to a single application at $1.1 \mathrm{~kg} \cdot \mathrm{ha}^{-1}$ (Table 4). In 1991, diclofop applied at $0.6 \mathrm{~kg} \cdot \mathrm{ha}^{-1}$ on $15 \mathrm{June}$ did not reduce turfgrass quality. However, when a second application was made to the same plot on 17 July, the quality of the turfgrass was reduced $17 \%$ and required 5 weeks for recovery. In 1993, the initial application at 0.6 $\mathrm{kg} \cdot \mathrm{ha}^{-1}$ reduced turfgrass quality only $10 \%$, which was within an acceptable level. When a second application was made at the same rate on 17 July, the quality of creeping bentgrass was not affected. When diclofop was applied at $0.6 \mathrm{~kg} \cdot \mathrm{ha}^{-1}$ on 17 July plus 15 Aug., the quality of creeping bentgrass was below the 90\% acceptable level for a longer period during 1991 than when treatments were made 15 June plus 17 July. There was no difference from dates of sequential treatments during 1993. In some instances, a single application of diclofop at $0.6 \mathrm{~kg} \cdot \mathrm{ha}^{-1}$ controlled goosegrass effectively (Johnson and Murphy, 1994). If this does occur, a second application should be omitted.

These results show that creeping bentgrass grown under stress conditions in the southeastern United States can be safely treated with dithiopyr EC $\left(\leq 1.7 \mathrm{~kg} \cdot \mathrm{ha}^{-1}\right)$ and $\mathrm{G}(\leq 1.1$ $\mathrm{kg} \cdot \mathrm{ha}^{-1}$ ) when applied as preemergence treatments in late February or early March. However, the use of diclofop, MSMA, and MON 12051 may cause various degrees of turfgrass discoloration. When diclofop is used for postemergence goosegrass control, the rate should be limited to $0.6 \mathrm{~kg} \cdot \mathrm{ha}^{-1}$. Treatments should be initiated in June and repeated at the same rate for a 4-week interval only if needed for effective goosegrass control. Quinclorac $\left(\geq 0.56 \mathrm{~kg} \cdot \mathrm{ha}^{-1}\right)$ applied in June severely injured creeping bentgrass and should not be used as a postemergence crabgrass herbicide on bentgrass under summer stresses.

\section{Literature Cited}

Bhowmik, P.C. and B.M. O'Toole. 1991. New tools for selective control of crabgrass in cool-season turfgrass. Proc. Northeastern Weed Sci. Soc. 45:116.

Chism, W.J. and S.W. Bingham. 1991. Postemergence control of large crabgrass Digitaria sanguinaliswith herbicides. WeedSci.39:62-66.

Table 4. Effect of rates and dates of diclofop application on quality of creeping bentgrass maintained as a putting green at different evaluation dates, Griffin, Ga.

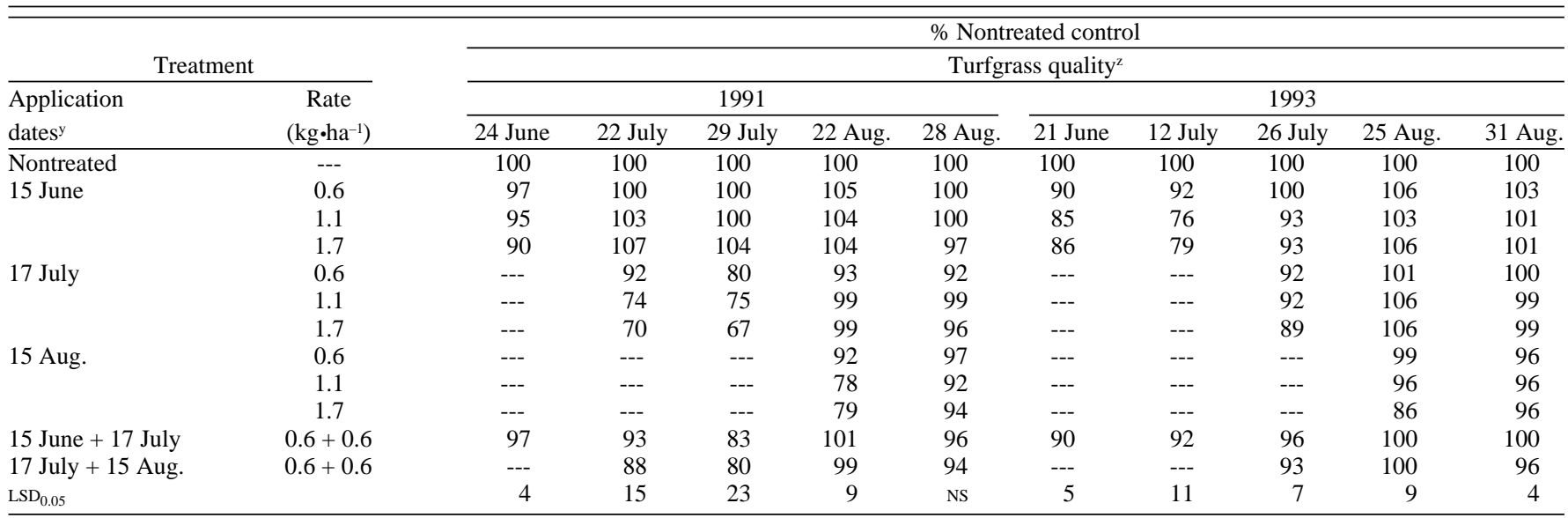

Turfgrass quality ratings were based on percent of nontreated control.

${ }^{y}$ Diclofop was applied at the given dates \pm 2 days. 
Dernoeden, P.H. 1987. Phytotoxic effects of some herbicides applied to bentgrass. Proc. Northeastern Weed Sci. Soc. 41:224-228.

Dernoeden, P.H., N.E. Christians, J.M. Krouse, and R.G. Roe. 1993. Creeping bentgrass rooting as influenced by dithiopyr. Agron. J. 85:560-563.

Dernoeden, P.H. and J.M. Krouse. 1991. Selected crabgrass control evaluations for Maryland in 1990. Proc. Northeastern Weed Sci. Soc. 45:117-118.

Johnson, B.J. 1975. Postemergence control of large crabgrass and goosegrass in turf. Weed Sci. 23:404-409.

Johnson, B.J. 1982. Oxadiazon treatments on overseeded putting-green turf. Weed Sci. 30:335-338.
Johnson, B.J. 1987. Tolerance of bentgrass to dates and frequency of preemergence herbicide treatments. Agron. J. 79:992-996.

Johnson, B.J. 1990. Herbicide $\times$ annual fertility programs influence on creeping bentgrass performance. Agron. J. 82:27-33.

Johnson, B.J. 1994. Frequency of quinclorac treatments on bermudagrass tolerance and large crabgrass control. J. Turfgrass Mngmt. (In press.)

Johnson, B.J. and T.R. Murphy. 1989. Summer annual weed control in turfgrass. Georgia Agr. Res. Bul. 388.

Johnson, B.J. and T.R. Murphy. 1993. Summer weed control with herbicides in turfgrasses. Georgia Agr. Res. Bul. 411
Johnson, B.J. and T.R. Murphy. 1994. Postemergence control of summer weeds in turfgrasses. Georgia Agr. Res. Bul. 413

McCarty, L.B. 1991. Goosegrass (Eleusine indica) control in bermudagrass (Cynodon spp.) turf with diclofop. Weed Sci. 39:255-261.

SAS Institute. 1982. SAS user's guide. SAS Institute, Cary, N.C.

Sciarappa, W.J. 1991. BAS 514-Approaches to selectivity and efficacy in bentgrass and bluegrass. Proc. Northeastern Weed Sci. Soc. 45:144.

Shim, S.R. and B.J. Johnson. 1992. Response of creeping bentgrass to spring-applied herbicides. HortScience 27:237-239. 